THE

PHILOSOPHY

OF

LITERARY

FORM 



\section{Kenneth Burke}

\section{THE \\ PHILOSOPHY \\ $\mathrm{OF}$ \\ LITERARY \\ FORM}

Studies in Symbolic Action

THIRD EDITION

UNIVERSITY OF CALIFORNIA PRESS BERKELEY, LOS ANGELES, LONDON 
University of California Press Berkeley and Los Angeles, California University of California Press, Ltd. London, England

Copyright 194I, 1967 by Louisiana State University Press Third Edition, Revised Copyright (C) 1973 by The Regents of the University of California.

ISBN: 0-520-02484-6 (cloth bound) 0-520-02483-4 (paper-bound) Library of Congress Catalog Card Number: 72-93526

Printed in the United States of America

\section{TO J. S. WATSON, JR.}

Out of these several years Since the days of The Dial Amicably indeed 